\title{
Space Transformation in Residential House Small Entrepreneurs Banana Sale
}

\author{
Rinaldi Mirsa $^{1 *}$, Muhammad ${ }^{2}$, Fidyati $^{1}$, Eri Saputra $^{1}$, Muhammad Rumiza $^{1}$ \\ ${ }^{I}$ Department of Architectural Engineering, Universitas Malikussaleh, Aceh, Indonesia \\ ${ }^{2}$ Department of Chemical Engineering,Universitas Malikussaleh, Aceh, Indonesia \\ *Corresponding author e-mail: rinaldi@ unimal.ac.id
}

\begin{abstract}
Manuscript received 15 August 2021; revised 1 Sept 2021; accepted 15 Sept 2021. Date of publication 4 Nov 2021
Abstract

Space transformation occurs in line with the needs and availability of resources owned by space users. The arrangement and utilization of space is carried out to optimize the function of the space owned and the limited space owned by the space user requires an adjustment in the use of the space owned to achieve business goals as well as the comfort of the living environment. Pante Bidari is a banana sale producing area in Aceh, which is located in East Aceh Regency, where the majority of the people work as small entrepreneurs and workers in the Banana Sale Industry. The process carried out when producing Pisang Sale uses a special room consisting of a storage room, peeling room, sale room and packaging room. This study aims to determine how the transformation of space in a small banana sale house. The method used in this research is a qualitative method. This study found that the spatial transformation that occurred in the small businessman's house of Pisang Sale in Pante Bidari District, East Aceh Regency is one way to optimize the utilization and utilization of space, so that the Pisang Sale production room consists of storage room, stripping room, sale room and packaging room. using residential space as an aspect of activity in residential homes, so that ongoing activities are not disturbed by other activities, residential space in terms of space dimensions there are changes that include addition, reduction and movement of space aimed at adjusting space requirements. Judging from the spatial relationship, there are several spaces that are far from each other and close to each other, so that access to activities carried out can optimize the function of the space.
\end{abstract}

Keywords: Transformation, Residential House, Production Room, Living Room, Banana Sale.

\section{Introduction}

Space transformation occurs in line with the needs and availability of resources owned by space users [1]. The arrangement and utilization of space is carried out to optimize the function of the space owned and the limited space owned by the space user requires an adjustment in the use of the space owned in order to achieve business goals as well as the comfort of their living environment. Pante Bidari is a banana sale producing area in Aceh, located in East Aceh Regency, where the majority of the people work as small entrepreneurs and workers in the Banana Sale Industry. Pisang Sale is a typical souvenir of East Aceh Regency whose marketing coverage has reached North Sumatra and all regions in Aceh [2]. The process carried out when producing Pisang Sale uses a special room consisting of a storage room, peeling room, sale room and packaging room. This study aims to determine how the transformation of space in a small banana sale house. The method used in this research is a qualitative method [3]. This study found that the spatial transformation that occurred in the residence of a small businessman Pisang Sale in Pante Bidari District, East Aceh Regency is one way to optimize the arrangement and utilization of space functions, so that the Pisang Sale production space consists of a storage room, stripping room, sale room and the packaging room uses the residential space as an aspect of activity in the residence, so that the ongoing activities are not disturbed by other activities, the residential space in terms of the dimensions of the space there are changes which include addition, reduction and movement of space aimed at adjusting space requirements [4].

\section{Literature Review}

\subsection{Space Transformation}

Transformation does not only change physical elements in space but is also a process of adding to space, such as the theory proposed by Habraken which explains that there are 3 causes of changes in space due to changes in the constituent elements [5], namely as follows:

1. Addition, is the process of adding elements to a space that causes changes to occur.

2. Elimination is the process of reducing/removing one element in space so that a change occurs.

3. Displacement (movement), is the process of moving or moving an element of space so that a change occurs. 


\subsection{Definition of Space}

Space is "emptiness" that exists around us or objects or objects, the space contained within is more essential than the material, namely, mass [6]. Then, the space is formed by three elements forming space, namely the floor, walls, and roof. From some of these theories, it can be concluded that the notion of space is a void that is limited by three elements, namely the floor at the bottom, the walls around the room, and the roof as the upper barrier which functions as a place for various activities to be carried out [7] [8].

\subsubsection{Floor}

According to Karso, the main function of the floor is to cover the lower space. Others are to support the loads in the space [9].

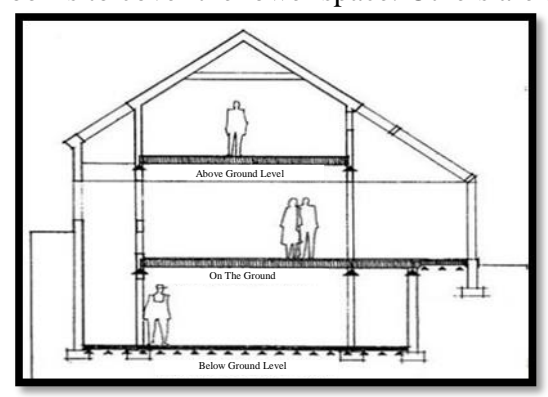

Fig 1. Floor

Source: https://slideplayer.info/slide/2285820/

\subsubsection{Ceiling}

The ceiling is a plane or surface that lies above the normal human line of sight. The ceiling serves as a protector or floor covering. This field is the roof as well as the space-forming element with the plane below it. Differences in height and shape of the ceiling can show visual differences or zones from a wider space, and people can feel different activities in that space [10] [11].

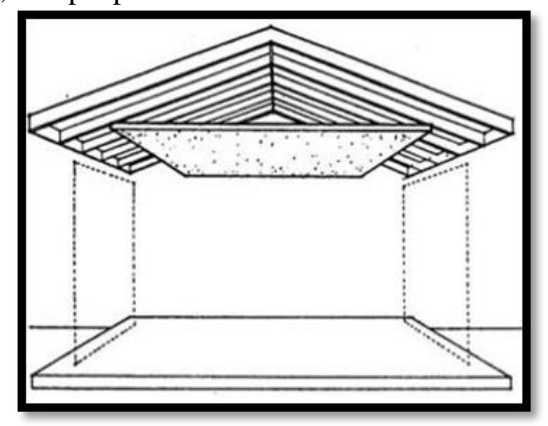

Fig 2. Ceiling

Source: https://slideplayer.info/slide/2285820

\subsubsection{Wall}

According to Karso, the wall is a space-forming element that functions as a load bearer on it and an element that must be strong enough to withstand 3 main forces, namely horizontal pressure, vertical pressure, vertical load, and bending power due to the vertical load [12] [13].

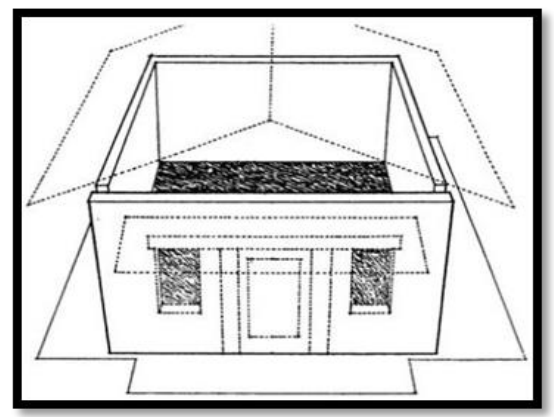

Fig 3. Wall

\subsection{Residential home}

Source: https://slideplayer.info/slide/2285820

The notion of a house is a structural phenomenon whose form and organization are strongly influenced by the cultural environment it has and is also closely related to the lives of residents [14]. A house is a building whose structure is shaped according to the needs of the occupants' activities and the building has functioned as a means of life to accommodate social, educational, engagement, business, and social activities. as well as various other activities related to residents.

\subsection{Industrial Space in Residential House}

The industry is all activities organized by people engaged in commerce and production in which the field provides goods and services for the needs of maintaining and improving their standards and quality of life [15]. The residential industry is a small industrial group with 1-4 employees who are members of their own families [16]. 


\subsection{Spatial Planning and Utilization}

The division of space that occurs in production activities and inhabiting activities will require separate spaces and areas in the dwelling house and the spatial distribution of these activities will not be the same in each house, because they have different arrangements patterns depending on the process and process. inhabiting activities [17]. The arrangement and use of space are related to the grouping of space based on the nature and function of space as explained that typology is the study of the type of grouping of objects that have the same formal structure [18]. In this case also explained that the industrial space which is separated from the inhabited space but is in the same space is called a balanced typology [19].

\section{Method}

This study uses a qualitative descriptive method which is an approach that is carried out in detail regarding the transformation of space in a residential house and the use of production space and living space in one building as well as the division of space to accommodate various activities carried out in the building [20]. In addition, this research also refers to local wisdom and the profession of the research subject who is a small businessman Pisang Sale located at the research location so that the arrangement of the production building is adjusted to the language used by residents around Pante Bidari District, East Aceh Regency.

\section{Result and Discussion}

Pante Bidari District is the largest Banana Sale producing area in Aceh Province with the majority of its people working as small entrepreneurs and workers in the Banana Sale industry, Pante Bidari District which is one of the sub-districts whose people work as small Banana Sale entrepreneurs.

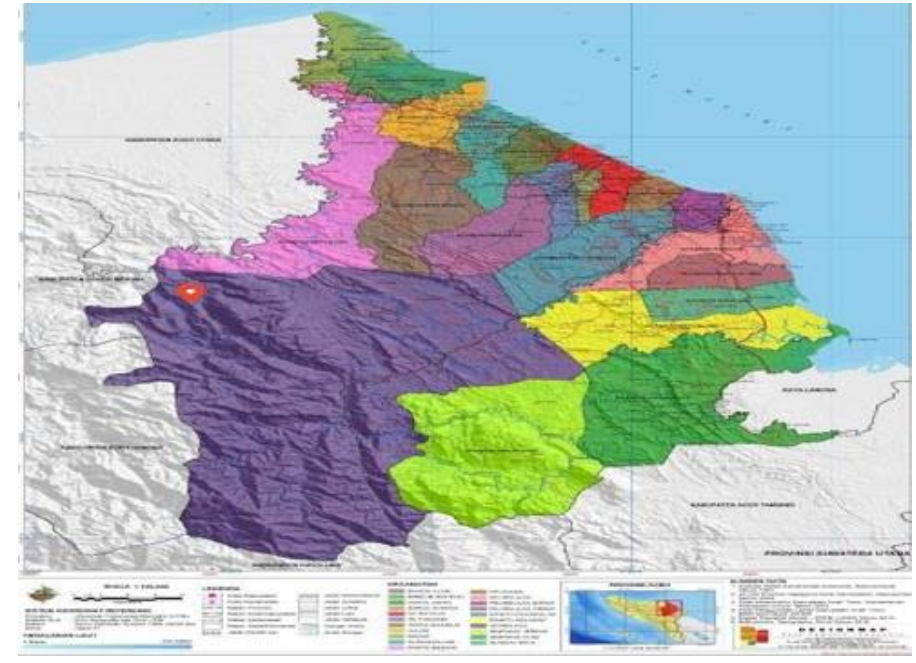

Fig 4. East Aceh Administration Map Source: Google, 2021

\subsection{History of Banana Sale}

Pisang Sale is one of the snack products made from monkey bananas (banana wak) which is a food that is a typical souvenir of East Aceh Regency originating from smoked bananas [2]. Pisang Sale production began in 1937 which was initiated by Peutua Hasan and Pang Puteh who had the idea to utilize millions of ripe banana bunches simultaneously without anyone being able to consume them when the Monkey Banana Tree grew wildly. Peutua Hasan and Pang Puteh are siblings who took the initiative to preserve bananas by smoking bananas and then wrapping them in banana leaves and then starting to sell them. The production of Pisang Sale which is currently developing at Pante Bidari began in 1957 when the Banana Sale trade began to spread to East Aceh, the packaging of the Banana Sale which has been growing is currently using plastic with various packaging sizes [21].

\subsection{Banana Sale Production Process}

The Pisang Sale management process, which starts from raw bananas that are left to stand for 3 days, aims to wait until they are ripe.

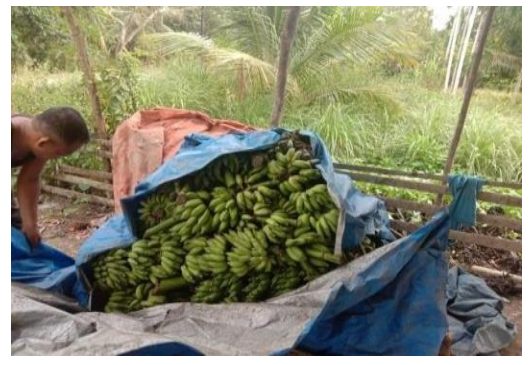

Fig 5. Occupancy/Season Process 
Then the bananas that are ripe and ready for sale, are peeled first and cleaned of skin and bunches.

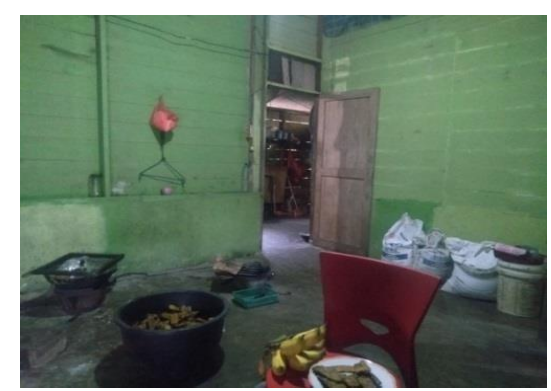

Fig 6. Banana Peeling Process

then sold/smoked for 2 days in a special room which aims to reduce the water content and concentrate the sugar content as a natural flavoring that makes the typical taste of Pisang Sale.

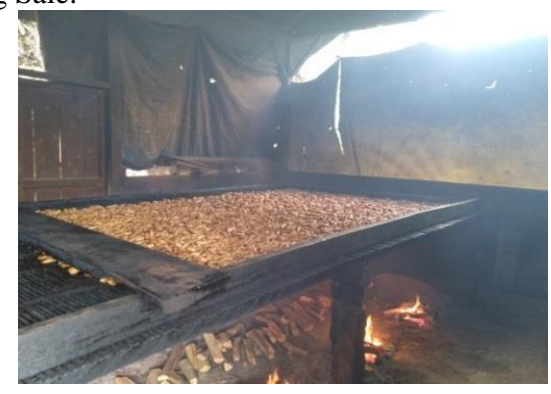

Fig 7. Banana Slicing Process

After the sale process, Pisang Sale that is ready for consumption is packaged in plastic according to the size and weight that has been determined by each business owner.

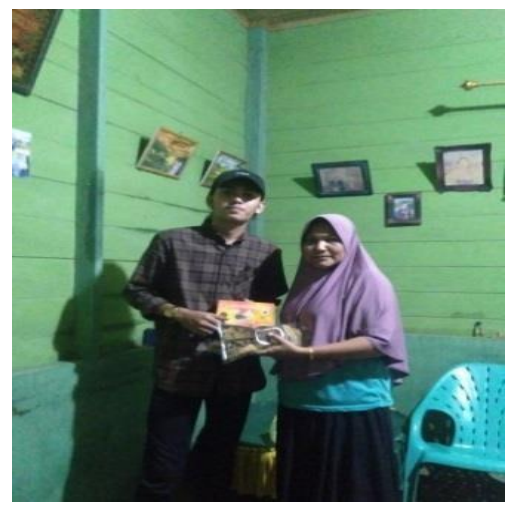

Fig 8. Banana Packaging

\subsection{Transformation in the Small Banana Sale Industry}

The industry studied in this study is the banana sale business which was founded by Mrs. Khaira in 2009, the transformation that occurred in the residential building of Mrs. Khaira consisted of adding one room in her house which was used as a place for selling bananas, because in 2009 Mrs. Khaira started producing Banana Sale industry. The addition of space will increase the area of the house it occupies, from the base it only has an area of $7 \mathrm{~m} \mathrm{x} 17.5 \mathrm{~m}$ so that in 2009 it had an area of $9 \mathrm{~m} \times 22 \mathrm{~m}$. which consists of several rooms in the house. For spaces such as bedrooms, living room, kitchen and toilets remain the same size, while for the sale area is a room that was added in 2009 with an area of $5 \mathrm{~m} \times 8 \mathrm{~m}$.

From 2015 until now there has been a lot of additional space because Mrs. khaira got a help house from the sub-district which used to have an area of $9 \mathrm{~m} \times 22 \mathrm{~m}$, now it has an area of $15 \mathrm{~m}$ x $22 \mathrm{~m}$. For additional space, there is a living room with an area of $4 \mathrm{~m} \times 6 \mathrm{~m}$, two bedrooms for children with an area of $3 \mathrm{~m} \mathrm{x} 3 \mathrm{~m}$, while the room that used to function as a bedroom is now used as a peeling room because considering the peeling area, a special room is needed such as cleaning. banana. The peeling room has an area of $7 \mathrm{~m} \times 3 \mathrm{~m}$, for other rooms it is still the same as the previous size because there is no change unless the bedroom changes its function into a peeling room. 


\subsubsection{Production Room in the Small Banana Sale Industry}

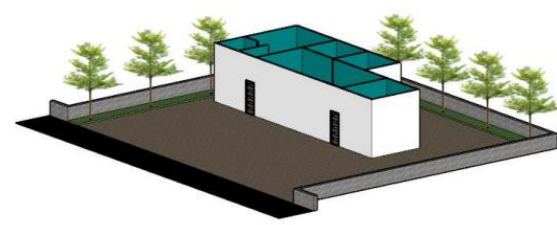

Fig 9. Production Room Base

Mrs. Khaira has lived in Pante Panah, District of Pante Bidari since 2007. Before Mrs. Khaira produced Pisang Sale, the basic plan of her house was not too big and not too small with an area of $9 \mathrm{~m} \times 17 \mathrm{~m}$.

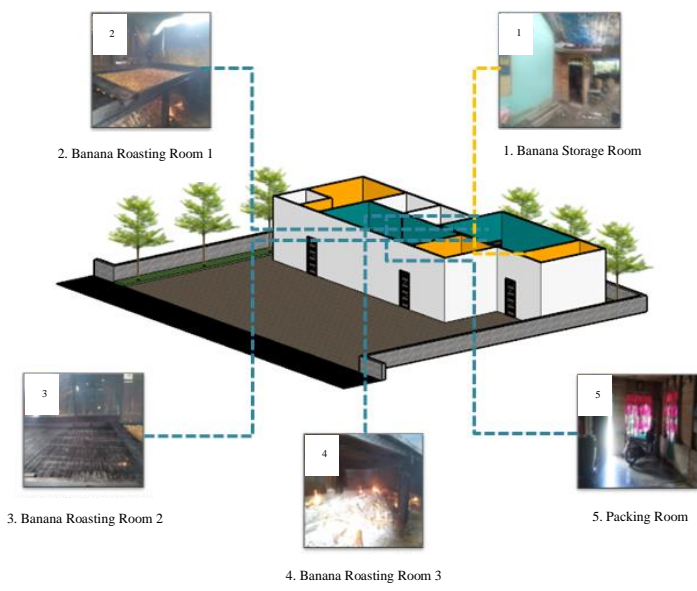

Fig 10. Beginning of Production Room

The Pisang Sale industrial production room was initially produced in $2009-2015$ consisting of a primary production room and a second production room, where the required space includes a storage room, peeling room, saleroom, and packing room[22]. At the beginning of the production of the Pisang Sale industry, Mrs. Khaira used a special room for banana storage, which was covered with tarpaulin. As for the banana peeling area, the kitchen room is used as an area for peeling bananas after being left for 3 days. Peeling bananas takes one day before slicing. Then for the salad, Ibu Khaira uses a special room for the sale area, because when doing the salaen it takes two days. After selling the bananas for two days, packing is done before being taken to the place where the Banana Sale is sold. For the packing area, Mrs. Khaira uses the living room so it takes one day because, at the beginning of production, Mrs. Khaira can produce $100 \mathrm{~kg}$ of Banana Sale in one production.

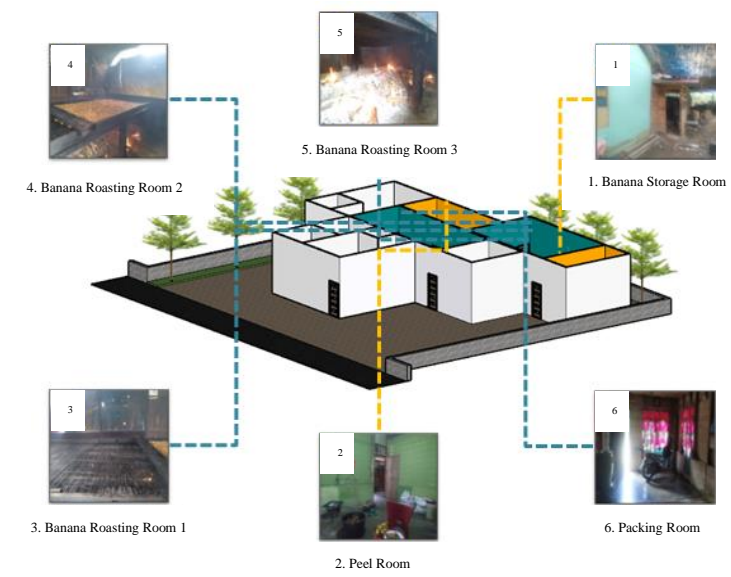

Fig 11. Current Production Room.

The Pisang Sale industrial production room currently consists of a primary production room and a second production room [23]. The primary production room is a place that accommodates goods and raw materials such as bananas and wood which are needed during the banana sale process. While the secondary industrial room is functioned as an auxiliary room to accommodate production supplies when needed. The primary production room consists of two rooms, namely the peeling room and the storage room. Meanwhile, the secondary production room also consists of two rooms, namely the salesroom and the packing room. The primary production room is adjacent to the secondary function room, such as a peeling room with a banana storage room. While the secondary production room is like a salesroom with space for the packing area. This production room meets the needs of space and activities when producing Banana Sale because all rooms have their respective functions to produce Banana Sale except the packing area which uses the family room as a packing room. 


\subsubsection{Occupancy Room In small banana sale industry (Activity)}

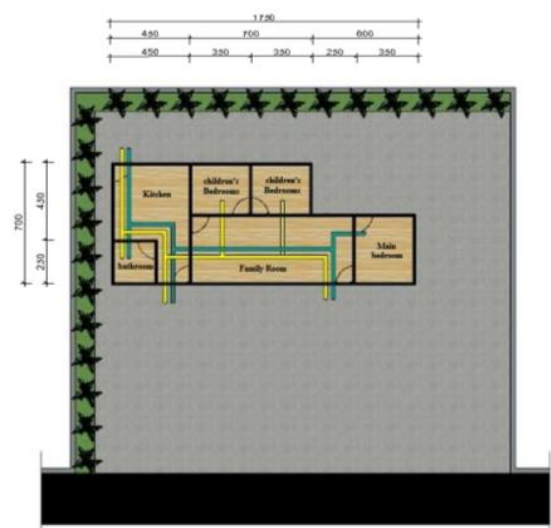

Fig 12. Basic Residential Plan (Activity)

The basics of Ibu Khaira's house, which was occupied in 2007 as a place to live, do activities in the house as a place to rest, eat, and drink.

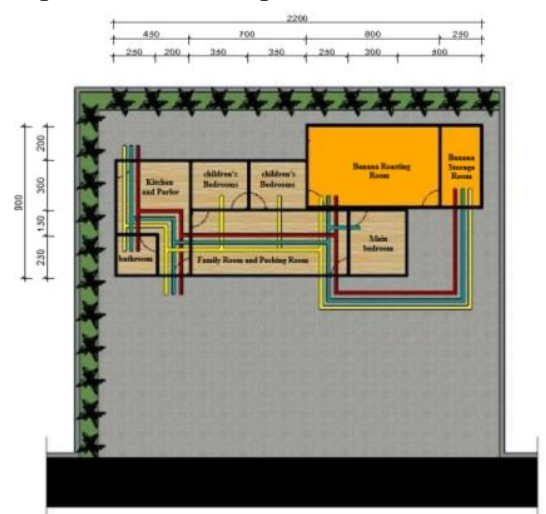

Fig 13. Initial Residential Plan (Activity)

Mrs. Khaira's house is used as a residence as well as a place for the production of the Banana Sale industry. At the beginning of production, many activities were carried out in residential homes. Parents who carry out daily activities at home starting from cooking, resting, and selling bananas.

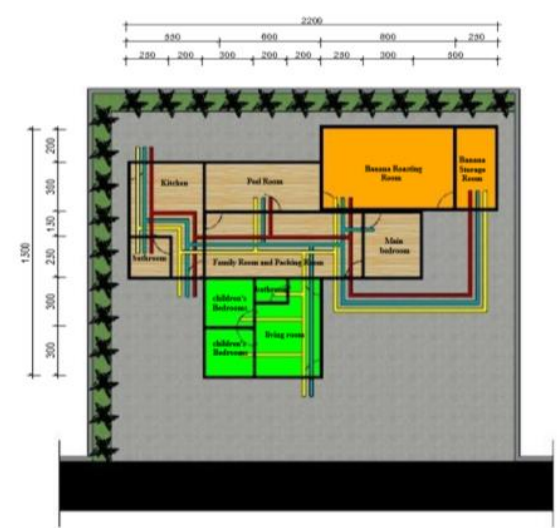

Fig 14. Current Residential Plan (Activity)

Mrs. Khaira's house is not only used as a place to live but also as a place for the production of the Banana Sale industry. Daily activities are used for resting places, starting from the bedroom, only 2 children and parents are allowed to enter the room. For rooms such as the kitchen, family room, and bathroom, only parents, children, and workers are allowed to enter the room, while those who visit must first ask permission from the owner when they want to enter the room. 


\subsubsection{Occupancy Space In small banana sale industry (Space Dimension)}

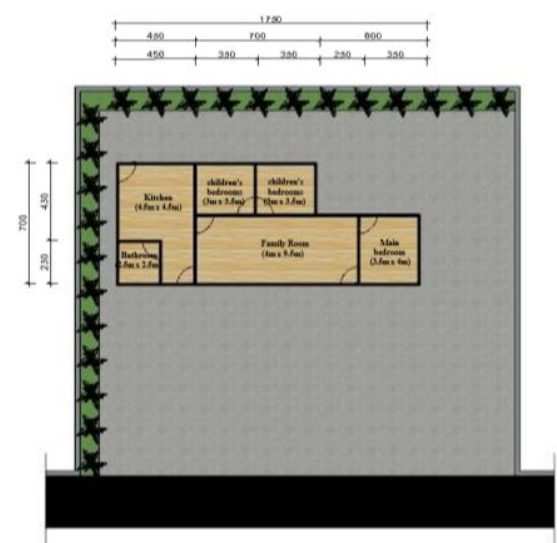

Fig 15. Current Residential Plan (Activity)

The basic plan of Mrs. Khaira's house has an area of $7 \mathrm{~m} \times 17.5 \mathrm{~m}$. where several rooms have their respective dimensions, including the living room with an area of $4 \mathrm{~m} \times 9.5 \mathrm{~m}$, the master bedroom with an area of $3.5 \mathrm{mx} 4 \mathrm{~m}$, children's bedroom 1 with an area of $3 \mathrm{~m} \times 3.5 \mathrm{~m}$, children's bedroom 2 with an area of $3 \mathrm{~m} \times 3.5 \mathrm{~m}$, then for the kitchen, it has an area of $4.5 \mathrm{mx} 4.5 \mathrm{~m}$, and a bathroom with an area of $2.5 \mathrm{mx}$ $2.5 \mathrm{~m}$.

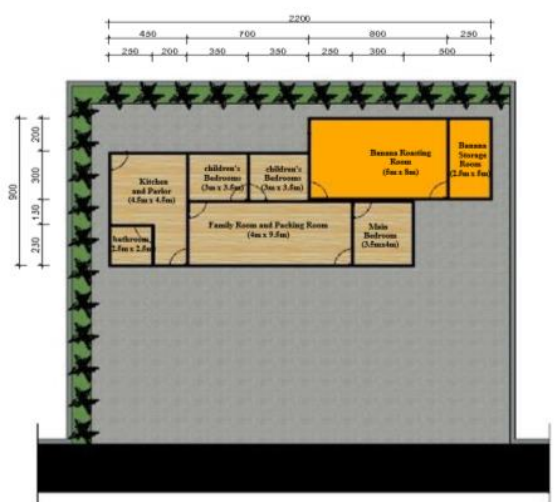

Fig 16. Initial Residential Plan (Spatial Dimensions)

In 2009 Ms. Khaira added one room in her house which was used as a place for selling bananas because in 2009 Ms. Khaira started producing the Banana Sale industry. The addition of space will increase the area of the house it occupies, from the base it only has an area of $7 \mathrm{~m} \times 17.5 \mathrm{~m}$ so that in 2009 it had an area of $9 \mathrm{~m} \times 22 \mathrm{~m}$. which consists of several rooms in the house. For spaces such as bedrooms, living room, kitchen and toilets remain the same size, while for the sale area is a room that was added in 2009 with an area of $5 \mathrm{~m} \times 8 \mathrm{~m}$.

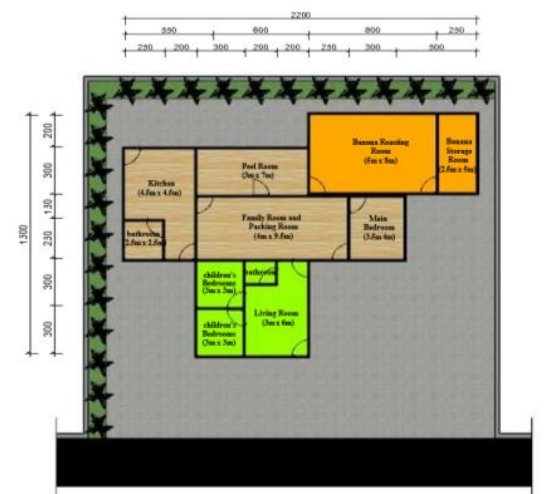

Fig 17. Current Residential Plan (Space Dimensions)

From 2015 to 2021, there will be a lot of additional space, because Ibu Khaira received a house from the sub-district which used to have an area of $9 \mathrm{~m} \times 22 \mathrm{~m}$, now it has an area of $15 \mathrm{~m} \times 22 \mathrm{~m}$. For additional space, there is a living room with an area of $4 \mathrm{~m} \times 6 \mathrm{~m}$, two bedrooms for children with an area of $3 \mathrm{~m} \times 3 \mathrm{~m}$, while the room that used to function as a bedroom is now used as a peeling room because, considering the peeling area, a special room is needed for cleaning. banana. The peeling room has an area of $7 \mathrm{~m} \times 3 \mathrm{~m}$, for other rooms it is still the same as the previous size because there is no change unless the bedroom changes its function into a peeling room. 


\subsubsection{Occupied Space In the small banana sale industry (Relationship Space)}

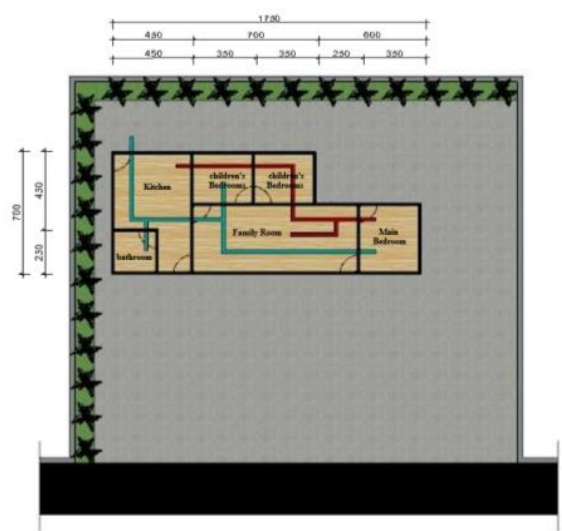

Fig 18. Basic Residential Plan (Spatial Relations)

At the beginning of the house where Mrs. Khaira lived, there was a spatial relationship between the rooms. Some spaces are far from each other and some are close to each other.

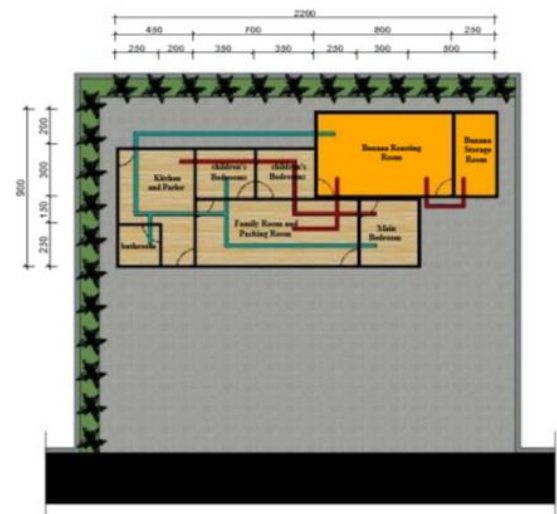

Fig 19. Basic Residential Plan (Spatial Relations)

In 2009 there was an additional room in the industrial residence of Mrs. Khaira, the added room is also related to other rooms. Like the master bedroom, children's bedroom 1, and the living room which is closely related to the sale area.

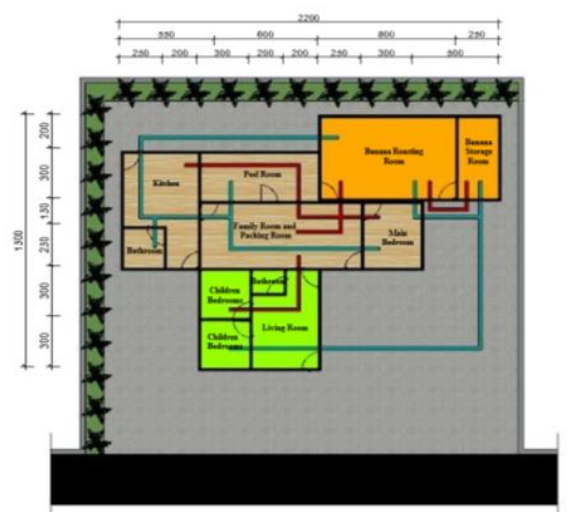

Fig 20. Current Residential Plan (Relationship Space)

Currently, there are many additional spaces in the house of Mrs. Khaira, so that the relationship between the space in the residence is increasing, such as the addition of two bedrooms, one living room, and one bathroom, which is becoming wider for Mrs. Khaira's house. The relationship of adjacent spaces at this time is like the master bedroom which is adjacent to the roasting room, the living room is adjacent to the peeling room, and also the roasting room, the saleroom is adjacent to the storage area so that it is easier to take bananas that have been ripened for 3 days. The living room and storage area are very far away because this living room is a new room that has been added, then the kitchen and salesroom are also very far away because they are blocked by the peeling room, as in the picture it is very clear when you see the relationship between adjacent and distant spaces. Therefore every dwelling needs to have a relationship space on each space. 


\subsubsection{Occupied Space In the small banana sale industry (Spatial Planning and Spatial Utilization)}

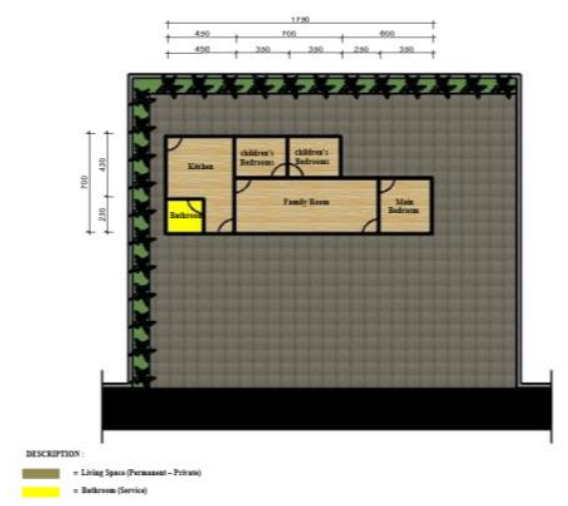

Fig 21. Basic Plan of Arrangement and Utilization

In early 2007, Ms. Khaira lived there was no primary production room and secondary production room because they had not yet produced. So for the available space, there is only a residential room that is used as a place to live, a residential room consisting of a private bedroom, then a semi-private living room and kitchen, and the last is a service bathroom. Private spaces are only allowed to enter for the owner, while semi-private spaces are only allowed to enter when there is prior permission from the owner, and for service rooms, anyone who is in the dwelling may enter. In the beginning, Mrs. Khaira lived in Pante Panah, which had not yet produced the Banana Sale industry, therefore there was only space that was used as a residence, which functioned permanently and could be used as a space to accommodate residents' domestic activities.

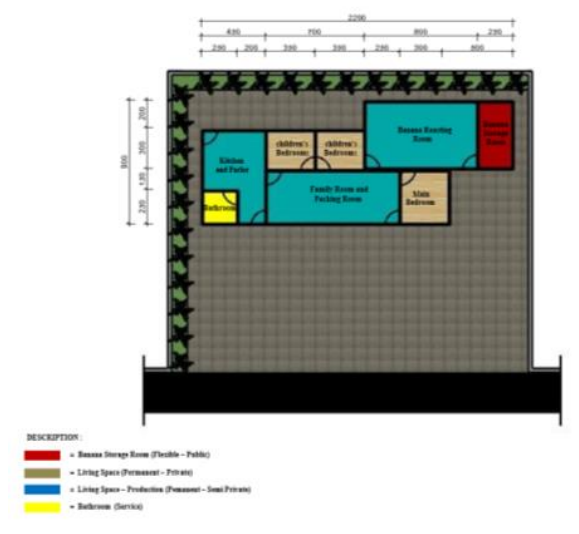

Fig 22. Initial Plan of Arrangement and Utilization

At the beginning of the Pisang Sale production, Mrs. Khaira had a spatial arrangement in her house which was divided into three, the first was the primary production room which was located in the living room and the kitchen room was a semi-private room that was not allowed to enter other than the owner and workers. Then the second is the secondary production room which is located on the side of the house and the back room, namely on the back which is used as a place for selling bananas, and the other side is used as a storage place for bananas. This space is a semi-private space that is not allowed to enter other than the owner and workers. The space that is used as a residence consists of a bedroom and a living room, for a private bedroom, other than the owner may not enter. then for the bathroom as a service room. At the beginning of the production, Mrs. Khaira used 2 rooms, namely the primary room which was used alternately because it functioned as a room that produced the Banana Sale industry. Then the secondary production space is used permanently, such as the saleroom which is used as a residence that is functioned permanently, which can be used as a space that accommodates the domestic activities of the occupants.

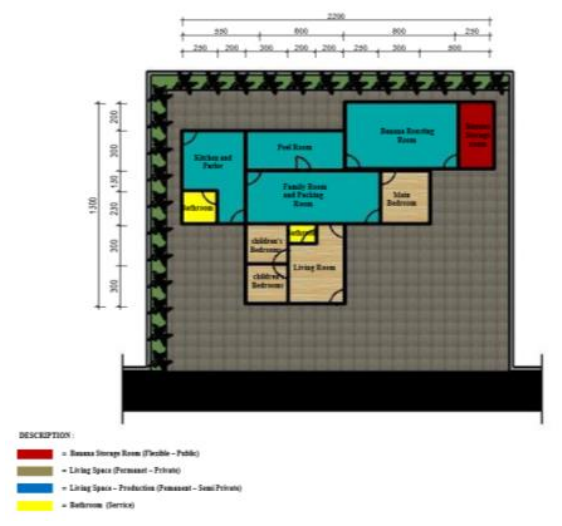

Fig 23. Current Arrangement and Utilization Plan 
The primary production room at the Pisang Sale mom khaira industry is currently located in the middle and back. This space is a semiprivate space that is not allowed to enter other than the owner and workers. The secondary production room is located on the side of the house and the back room, that is, the back is used as a peeling room and next to the house is used as a storage area. This space is a semiprivate space that is not allowed to enter other than the owner and workers. The space that is used as a residence in the Pisang Sale industry by Mrs. Khaira consists of a bedroom, which is private which cannot enter except by the owner. The living room which is used as a residence is semi-private, which is only allowed to enter the owner and workers, then the bathroom is used as a service room. The primary production room is used permanently because it functions as a space that produces the Banana Sale industry. The secondary production space is used interchangeably or flexibly because it functions as an additional space for production activities. Then the space that is used as a residence that is functioned permanently can be used as a space that accommodates residents' domestic activities

\section{Conclusion}

The spatial transformation that occurs in the residence of the Pisang Sale small businessman in Pante Bidari District, East Aceh Regency is one way to optimize the arrangement and utilization of space functions, so that the Pisang Sale production space which consists of storage room, stripping room, salesroom and packaging room uses space occupancy as an aspect of activity in residential homes so that ongoing activities are not disturbed by other activities, livable space in terms of spatial dimensions there are changes which include addition, reduction, and movement of space aimed at adjusting space requirements. Judging from the spatial relationship, several spaces are far from each other and close to each other, so that access to activities carried out can optimize the function of the space.

\section{References}

[1] V. P. Pertuz Peralta, A. B. Perez Orozco, N. C. Boscán Romero, M. D. socorro Bermudez Rojo, and C. Solorzano Bastidas, "Intellectual Capital: A Comparative View between Enterprises and Universities," Int. J. Adv. Sci. Eng. Inf. Technol., 2018, doi: 10.18517/ijaseit.8.2.3253.

[2] H. Dan and N. Kesumawati, "Studi Persepsi Konsumen Terhadap Pemasaran Sale Pisang Dalam Kemasan,” vol. 13, no. $2,2015$.

[3] D. K. Despotis and Y. G. Smirlis, "Data envelopment analysis with imprecise data," Eur. J. Oper. Res., 2002, doi: 10.1016/S03772217(01)00200-4.

[4] D. Kumar, "Power System Restoration Using Multilayer Perceptron," Int. J. Eng. Sci. Inf. Technol., vol. 1, no. 1, 2021, doi: 10.52088/ijesty.v1i1.35.

[5] H. NJ, Transformation Of The Site. Massachusetts. Combridge, 1982.

[6] R. Suraretja, Fungsi, Ruang, Bentuk Dan Ekspresi Dalam Arsitektur. 2007.

[7] I. Komara, E. Wahyuni, P. Suprobo, and K. Taşkin, "Assessing the Tensile Capacity of Cold-Formed Steel Connections using SelfDrilling Screws and Adhesive Materials,” Int. J. Adv. Sci. Eng. Inf. Technol., 2018, doi: 10.18517/ijaseit.8.2.4314.

[8] C. S. Silvia, M. Ikhsan, M. Safriani, and T. P. Gusmilia, "Efficiency Rainwater Harvesting at the Roof Campus Buildings," Int. J. Eng. Sci. Inf. Technol., vol. 1, no. 3, 2021, doi: 10.52088/ijesty.v1i3.80.

[9] M. Karso, . "Dasar - Dasar Desain Pelayanan Umum," in 1, 2010, p. 131.

[10] I. Ilah Nashruddin, Transformasi Bentuk Dalam Arsitektur. Kanvas Angan. 2003.

[11] N. V. T. Hang, "Education of Critical Thinking: A Possibility to Enhance the Effectiveness of Education in Vietnam," VNU J. Sci. Educ. Res., 2018, doi: 10.25073/2588-1159/vnuer.4122.

[12] I. Fitrianti, Transformasi Perpustakaan UI Dalam Mendukung Universitas Indonesia Menjadi Word Class University. Depok, 2012.

[13] M. J. N. Priestley, "Displacement-based seismic assessment of reinforced concrete buildings," J. Earthq. Eng., 1997, doi: $10.1080 / 13632469708962365$.

[14] A. Rapoport, House From Culture. Prentice Hall. New York, 1969.

[15] C. Koeswanto, "Strategi Pengembangan Bisnis pada PT. Putrasean Rubber Industri," Agora, vol. 4, no. 2, pp. 217-221, 2016.

[16] W. Hartono, "Transformasi ruang pada rumah tinggal penggiat komunitas reog di Pendukuhan Gunungsari Desa Bejiharjo, Kabupaten Gunungkidul," ARTEKS J. Tek. Arsit., vol. 4, no. 1, pp. 13-24, 2019.

[17] R. Mirsa, "Pembentukan Ruang Gender Melalui Aktivitas Membatik di Laweyan,” J. Shentong, vol. 2, p. $2,2019$.

[18] R. Mirsa, "Morfologi Kota Ponorogo," Yogyakarta, 2005.

[19] R. Mirsa, "Tipologi Ruang Industri dalam Rumah Tinggal," J. Shentong, vol. 3, p. 1, 2020.

[20] A. Wati, "KETERIKATAN TEMPAT BERMUKIM PADA PERMUKIMAN KUMUH DI MANGGARAI, JAKARTASELATAN," J. Ilm. Desan dan Konstr., vol. 17, no. 1, 2018.

[21] S. Fyka, L. Yunus, M. Limi, A. Hamzah, and D. Darwan, "Analisis Dampak Pengembangan Wisata Pulau Bokori Terhadap Kondisi Sosial Ekonomi Masyarakat Bajo (Studi Kasus di Desa Mekar Kecamatan Soropia)," HABITAT, vol. 29, no. 3, 2018, doi: 10.21776/ub.habitat.2018.029.3.13.

[22] A. Nugroho and M. N. Y. Rochdiani, Dini, "Analisis Saluran Pemasaran Sale Pisang (Studi Kasus pada Perajin Sale Pisang Basah di Desa Sindangbarang Kecamatan Karangpucung Kabupaten Cilacap)," J. Ilm. Mhs. AGROINFO GALUH, vol. 7, pp. 1-7, 2014.

[23] R. S. Febrianto, L. D. Wulandari, and H. Santora, "Spasial Ruang Pada Hunian Masyarakat Peladang-Muslim," Modul, vol. 17, no. 1, pp. 1-10, 2017. 